Ann. Biol. anim. Bioch. Biophys., I974, 14 (4-A), 65I-666.

\title{
THE VITELLINE MEMBRANE OF THE UNFERTILIZED HEN'S EGG : ELECTROLYTE AND WATER TRANSPORT
}

\author{
T. RYMEN and J. STOCKX \\ Laboratorium voor Fysiologische Scheikunde, \\ Rijksuniversiteit, Gent (Belgique)
}

\begin{abstract}
SUMMARY
In vitro measurements of different electrolyte fluxes and membrane potentials point to the fact that the ovovitelline membrane is charged and asymmetrical. It's directional specificity to ion transport and accompanying volume flux is described for several electrolytes. Specific effects are induced by phosphate ions. A number of experiments, showing the dependence of the phosphatemembrane interaction on several variables such as concentration, temperature and duration of the phosphate pretreatment, suggest that this interaction represents more than just the result of the membrane's ion exchange behaviour and that it may involve an enzymatic mechanism.
\end{abstract}

\section{IN'TRODUC'TION}

It is well known that the composition and physicochemical properties of egg white and yolk differ in many respects (PUCHER, I927 ; ROMANOFF and ROMANOFF, I949; NeEdham, I950 ; RoMANOFF, I960 ; GILBERT, I97I). As a consequence a great difference in osmotic pressure $(\simeq$ I.8 atm.) exists between white and yolk of freshly laid eggs that persists for at least two months, diminishing slowly in value (WLADIMIROFF, I926; RICE and YounG, I928; KEnzo, I929). Moreover the concentration differences are different for almost each substance present (STraUb and HoogerDUYN, I929). Moors and STOCKX, I968, and Moors, I969, found great differences in nucleolytic enzyme activities between white and yolk, the vitelline membrane acting as a barrier. These enzymes were shown to be subject to aggregation-dissociation equilibria, depending on concentration, temperature and ionic strength, the different aggregation forms showing different activities (Moors, I969; DE MOOR and STockx, I969). Moors, I969, finds also several nucleolytic enzymes of yolk and white in the membrane itself, probably in a modified (bound) state. ETHEREDGE et al. (I97I), HAALAND et al. (I97I) and RHEA and RosenBERG (I97I) identified a soluble and a 
membrane bound ATPase in the ovovitelline membrane. An ATPase of the white (mainly localized in thick white) was studied in this laboratory a few years ago (VAN MAELE, I 969). For all these reasons it is obvious that the ovovitelline membrane may play an active role in the morphogenesis of the chick. Despite earlier investigations (Straub and Hoogerduyn, I929; Needham, I93I ; Smith and Shepherd, I93I ; ORRU, I939, I940 ; JoRDANOV et al., I966 ; DE BOECK et al., I97I) the most important aspects of its permeability properties are still obscure. A few results about the membrane of unfertilized chicken eggs will be described in this paper.

\section{ME'THODS AND MA'TERIALS}

The membranes were from unfertilized white Leghorn eggs, less than a week old and kept at $I^{\circ} \mathrm{C}$. It was ascertained that ageing of the egg in these conditions does not interfere wich the membrane characteristics. After removal of the white and the chalazae, the blastodisc was cut out from the membranes, that were prepared by rinsing off adhering white and yolk with 0.9 p. Ioo $\mathrm{NaCl}$ and a wash with redistilled water, in a way that white and yolk sides were known. (DE BoEck et al., 197I). The most used experimental set-up consisted of two plexiglass cells equipped with water mantles interconnected so as to form one thermostatic unit (maintained at $20^{\circ} \mathrm{C}$, unless stated otherwise). Both compartments communicated by a circular hole with a diameter of $\mathrm{I} \mathrm{cm}$ and were provided with platinum electrodes, so as to form two cells for conductivity measurements. The membrane was pressed between them with the aid of Parafilm at the periphery. intervals.

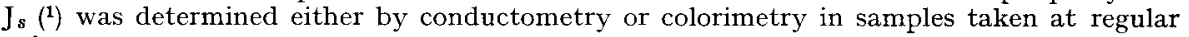

$\mathrm{J}_{v}\left({ }^{1}\right)$ was measured from the difference in levels read with a cathetometer. The electrical potential differences induced by $\mathrm{NaCl}$ were measured with $\mathrm{Cl}^{-}$specific electrodes (Orion, model 92 I $7 \mathrm{oo}$ ), yielding membrane potentials after correction for concentration and/or asymmetry potentials (junction potentials in the measuring circuit).

Experiments were performed at $\mathrm{pH} 5.8,7.0$ and 8.6

All neutral salt solutions were buffered at $\mathrm{pH} 5.8$ by $5 \times \mathrm{IO}^{-3} \mathrm{M}$ cacodylate buffer and at $\mathrm{pH} 7.0$ and 8.6 by $5 \times \mathrm{IO}^{-3} \mathrm{M}$ tris. Prior to use the membranes were soaked for one hour in o.I M of the same buffer as used in the experiments to be performed. Subsequently they were washed three times during five minutes in $5 \times \mathrm{IO}^{-3} \mathrm{M}$ of that buffer. When changing the concentration difference or reversing it the membranes were washed in the same way.

Phosphate or arsenate was adjusted with $\mathrm{NaOH}$ to the wanted $\mathrm{pH}$, starting from the acid components. In this case, the electrolytes are good buffers themselves and the membranes were used without further pretreatment. Redistilled water was used for washing them.

\section{RESULTS AND DISCUSSION}

\section{A. - Permeability coefficient and $\mathrm{NaCl}$ or $\mathrm{KCl}$ activity}

According to 'Teorell's extended "fixed charge theory " $\left({ }^{2}\right)$ (TEORELL, I953) and substituting concentrations by activities, the following equation holds for the flux

(1) $\mathrm{J}_{s}$ : solute flux, in mmoles $\min ^{-1} \mathrm{~cm}^{-2}$;

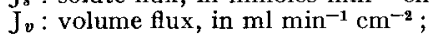

$\mathrm{W} \rightarrow \mathrm{Y} ; \mathrm{Y} \rightarrow \mathrm{W}:$ from white side to yolk side and vice versa.

(2) In Teorell's theory the fluxes of cations and anions $\left(\mathrm{J}_{i}^{+} ; \mathrm{J}_{i}^{-}\right)$are expressed as electrical currents (coulomb $\mathrm{min}^{-1} \mathrm{~cm}^{-2}$ ). They are related to $\mathrm{J}^{+}$and $\mathrm{J}^{-}$(fluxes in gram ion $\mathrm{min}^{-1} \mathrm{~cm}^{-2}$ ) by :

$$
\mathrm{J}^{+}=\frac{\mathrm{J}_{i}^{+}}{\mathrm{F}} \quad \text { and } \quad \mathrm{J}^{-}=\frac{\mathrm{J}_{i}^{-}}{\mathrm{F}}
$$


of a single I-I valent electrolyte across a moderately positively $\left({ }^{1}\right)$ charged membrane, in the absence of electrical current and for $a_{1}>a_{2}$ :

$$
\mathrm{J}^{+}=\mathrm{J}^{-}=\mathrm{J}_{s}=-\frac{\mathrm{RT}}{\delta \mathrm{F}} \frac{2 u v}{u+v}\left(\bar{a}_{2}^{+}-\bar{a}_{1}^{+}\right)-\left(\frac{\varphi_{2}-\varphi_{1}}{50 \cdot 4}\right) \cdot \omega \overline{\mathrm{X}}
$$

$a_{1}, a_{2}$ : electrolyte activities in the bathing solutions $\left(\mathrm{mol} \cdot 1^{-1}\right)$.

$\mathrm{J}_{s}$ : solute flux $\left(\mathrm{mmol} \cdot \mathrm{min}^{-1} \cdot \mathrm{cm}^{-2}\right)$.

$u$ and $v$ : absolute ion mobilities for positive or negative ions in the membrane $\left(\mathrm{cm}^{2} \cdot \min ^{-1} \cdot \mathrm{v}^{-1}\right)$.

$a_{1}^{+}, a_{2}^{+}$: positive ion activities in compartments $I$ and $2\left(\mathrm{~mol} \cdot 1^{-1}\right)$.

$\bar{a}_{1}^{+}, \bar{a}_{2}^{+}$: positive ion activities in the membrane on boundaries $\mathrm{I}$ and $2\left(\mathrm{~mol} \cdot 1^{-1}\right)$.

$r:$ The Donnan distribution ratio $; \bar{a}_{1}^{+}=r_{1} \cdot a_{1}^{+} ; \bar{a}_{2}^{+}=r_{2} \cdot a_{2}^{+}$.

$\varphi_{2}-\varphi_{1}$ : internal membrane potential $(\mathrm{mV})$.

$\omega \overline{\mathrm{X}}$ : constant membrane charge (equivalents $\cdot 1^{-1}$ ).

$$
\begin{aligned}
& \omega=+\mathrm{I} \text { for cations } \\
& \omega=-\mathrm{I} \text { for anions. }
\end{aligned}
$$

$\delta:$ membrane thickness $(\mathrm{cm})$.

$\mathrm{R}, \mathrm{T}$ and $\mathrm{F}$ have their usual meanings.

For high values of the membrane charge one gets approximately :

$$
\mathrm{J}_{s}=-\frac{\mathrm{RT}}{\delta \mathrm{F}} \cdot \frac{2 u v}{u+v}\left(\bar{a}_{2}^{+}-\bar{a}_{1}^{+}\right)
$$

and when the membrane charge vanishes $(\omega \overline{\mathrm{X}}=0)$ :

$$
\mathrm{J}_{s}=-\frac{\mathrm{RT}}{\delta \mathrm{F}} \cdot \frac{2 u v}{u+v}\left(a_{2}-a_{1}\right)
$$

or with

$$
\begin{aligned}
\mathrm{P} & =\frac{\mathrm{RT}}{\delta \mathrm{F}} \cdot \frac{2 u v}{u+v} \\
\mathrm{~J}_{s} & =-\mathrm{P}\left(a_{2}-a_{1}\right)
\end{aligned}
$$

Il this case $\mathrm{P}$ should remain constant with increasing activity difference, provided that $u$ and $v$ are constant, $i$. $e$. for small concentration changes. Greater changes in concentration produce a decrease of $u$ and $v$, resulting into a decrease of $\mathbf{P}$.

However our experimental results show, at each $\mathrm{pH}$, an increase of $\mathbf{P}$ (tables $\mathbf{I}$ and 2) with increasing activity differences. This can only be explained by assuming a charged membrane and is due to the variation of the Donnan distribution ratio with increasing concentration (LAKSHMINARAYANAIAH, I969).

\section{B. - Membrane potentials in the presence of $\mathrm{NaCl}$}

For a charged membrane the total potential $\left(\mathrm{E}_{m}\right)$, originating from concentration gradients, is composed of Donnan and diffusion potentials (TEORELL, I953).

$$
\mathrm{E}_{m}=\mathrm{E}_{\mathrm{Don}_{1}}+\mathrm{E}_{\mathrm{Don}_{2}}+\mathrm{E}_{\mathrm{diff}}
$$

(l) The assumption of positive membrane charges is arbitrary. 
$\mathrm{NaCl}$ and $\mathrm{KCl}$ fuxes and permeability coefficients as a function of activity differences and $p H$. All $\mathrm{NaCl}$ diffusion experiments were performed with the same membrane and are thus completely comparable (idem for $\mathrm{KCl}$ ).

Flux et coefficients de perméabilité pour $\mathrm{NaCl}$ et $\mathrm{KCl}$ en fonction de différences en activité et de $p H$. Dans tous les essais avec le $\mathrm{NaCl}$ on a fait emploi de la même membrane, de sorte que les résultats sont tout à fait comparables (idem pour $\mathrm{KCl}$ ).

(I) $\mathrm{C}_{2}$ was kept constant at $5 \cdot$ Io $^{-4} \mathrm{M}$ while $\mathrm{C}_{1}$ varied.

$\mathrm{C}_{2}$ égalait $5 \cdot$ Io $^{-4} \mathrm{M}, \mathrm{C}_{1}$ étant variable.

(2) Activities were calculated from the extended Debye-Hückel formula (GLAssTone, I946). Les activités ont été calculées par la formule élargie de Debye et Hückel.

(3) $\mathrm{J}_{v}=\mathrm{o}$ in all experiments.

$\mathrm{J}_{v}=\mathrm{o}$ partout.

TABLE I

\begin{tabular}{|c|c|c|c|c|c|c|}
\hline \multirow{2}{*}{$\begin{array}{c}\mathrm{pH} \\
\text { buffer }\end{array}$} & \multirow{2}{*}{$\begin{array}{c}\mathrm{C}_{1}-\mathrm{C}_{2}\left({ }^{1}\right) \\
10^{-4} \mathrm{~mol}^{-1} \mathrm{l}^{-1}\end{array}$} & \multirow{2}{*}{$\begin{array}{c}a_{1}-a_{2}\left({ }^{2}\right) \\
10^{-4} \mathrm{~mol} \cdot 1^{-1}\end{array}$} & \multicolumn{2}{|c|}{$\underset{10^{-4} \mathrm{mmol} \cdot \mathrm{min}^{-1} \cdot \mathrm{cm}^{-2}}{\mathrm{~J} \mathrm{aCl}}$} & \multicolumn{2}{|c|}{$\begin{array}{c}\mathrm{P}_{\mathrm{NaCl}} \\
10^{-4} \mathrm{~cm} \cdot \min ^{-1}\end{array}$} \\
\hline & & & $\mathrm{Y} \rightarrow \mathrm{W}$ & $\mathrm{W} \rightarrow \mathrm{Y}$ & $\mathrm{Y} \rightarrow \mathrm{W}$ & $\mathrm{W} \rightarrow \mathrm{Y}$ \\
\hline $\begin{array}{c}5 \cdot 10^{-3} \mathrm{M} \\
\text { cacodylate } \\
\text { pH } 5.8\end{array}$ & $\begin{array}{r}95 \\
195 \\
345 \\
495\end{array}$ & $\begin{array}{r}84.7 \\
168.2 \\
287.5 \\
401.7\end{array}$ & $\begin{array}{c}1.92 \pm 0.03 \\
4.30 \pm 0.06 \\
7.70 \pm 0.14 \\
10.6 \pm 0.2\end{array}$ & $\begin{array}{c}1.92 \pm 0.03 \\
4.20 \pm 0.06 \\
7.30 \pm 0.15 \\
10.0 \pm 0.2\end{array}$ & $\begin{array}{l}227 \pm 4 \\
256 \pm 4 \\
268 \pm 5 \\
264 \pm 5\end{array}$ & $\begin{array}{l}227 \pm 4 \\
250 \pm 4 \\
254 \pm 6 \\
249 \pm 5\end{array}$ \\
\hline $\begin{array}{c}5 \cdot 10^{-3} \mathrm{M} \\
\text { tris } \\
\text { pH } 7.0\end{array}$ & $\begin{array}{r}95 \\
195 \\
345 \\
495\end{array}$ & $\begin{array}{r}83.9 \\
166.8 \\
285.9 \\
399.9\end{array}$ & $\begin{array}{l}1.56 \pm 0.03 \\
3.30 \pm 0.12 \\
6.60 \pm 0.06 \\
9.70 \pm 0.13\end{array}$ & $\begin{array}{l}1.56 \pm 0.03 \\
3.25 \pm 0.06 \\
6.50 \pm 0.11 \\
9.40 \pm 0.10\end{array}$ & $\begin{array}{l}186 \pm 4 \\
198 \pm 7 \\
231 \pm 2 \\
243 \pm 4\end{array}$ & $\begin{array}{l}196 \pm 4 \\
195 \pm 4 \\
227 \pm 4 \\
235 \pm 3\end{array}$ \\
\hline $\begin{array}{c}5 \cdot 10^{-3} \mathrm{M} \\
\text { tris } \\
\mathrm{pH} 8.6\end{array}$ & $\begin{array}{r}95 \\
195 \\
345 \\
495\end{array}$ & $\begin{array}{r}84.7 \\
168.2 \\
287.5 \\
401.7\end{array}$ & $\begin{array}{l}1.32 \pm 0.02 \\
2.70 \pm 0.03 \\
5.50 \pm 0.03 \\
8.45 \pm 0.06\end{array}$ & $\begin{array}{l}1.14 \pm 0.03 \\
2.45 \pm 0.06 \\
5.40 \pm 0.08 \\
8.70 \pm 0.14\end{array}$ & $\begin{array}{l}156 \pm 3 \\
161 \pm 2 \\
191 \pm 1 \\
210 \pm 2\end{array}$ & $\begin{array}{l}135 \pm 3 \\
146 \pm 4 \\
188 \pm 3 \\
217 \pm 4\end{array}$ \\
\hline
\end{tabular}

TABLE 2

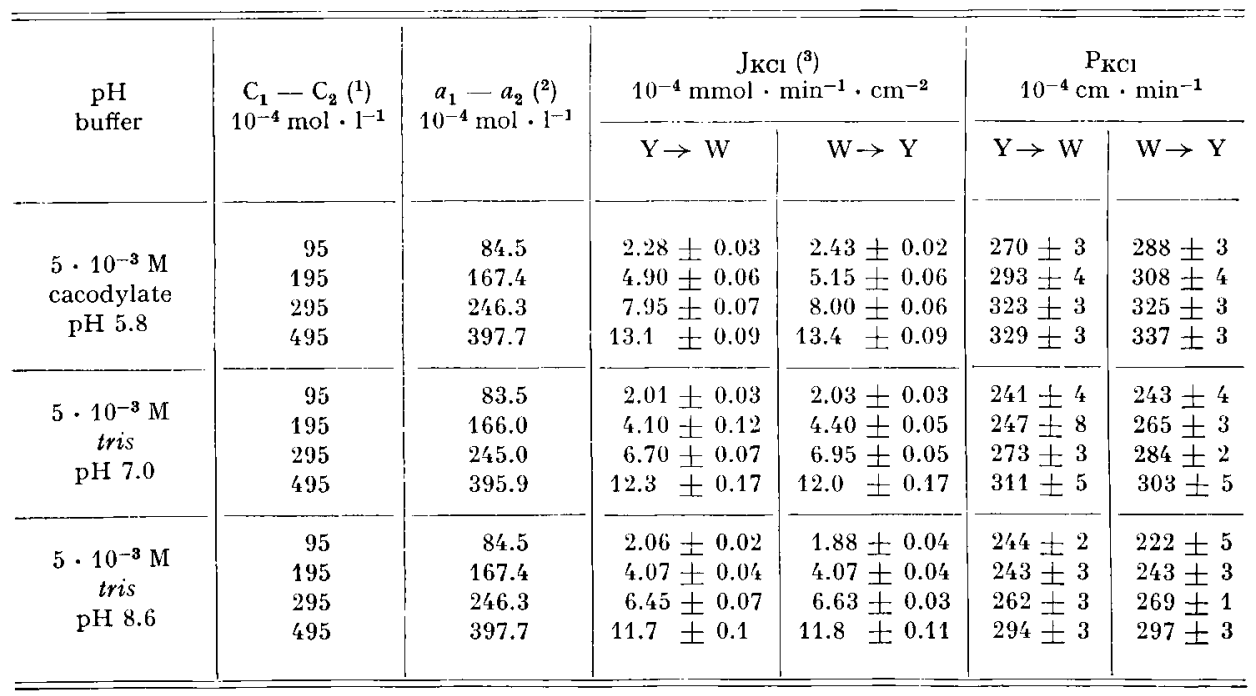


For our experimental conditions (I-I valent electrolyte in $5 \mathrm{X} \mathrm{Io}^{-3} \mathrm{M}$ buffer), and with the same assumptions as for the theoretical treatment of $\mathrm{J}_{s}$, we find :

$$
\mathrm{E}_{m}=\frac{\mathrm{RT}}{\mathrm{F}} \ln \frac{r_{2}}{r_{1}}-\frac{\mathrm{RT}}{\overline{\mathrm{F}}} \frac{u-v}{u+v} \ln \frac{\bar{a}_{2}^{+} u+\bar{a}_{2} v}{\bar{a}_{1}^{+} u+\bar{a}_{\mathrm{i}} v}
$$

For an uncharged membrane $(\omega \overline{\mathrm{X}}=0)$ :

$$
\begin{gathered}
r_{1}=r_{2}=\mathrm{I} \\
\bar{a}_{\overline{1}}=a_{1}^{-} \quad \bar{a}_{2}^{-}=a_{2}^{-} \\
\bar{a}_{1}^{+}=a_{1}^{+} \quad \bar{a}_{2}^{+}=a_{2}^{+} \\
\mathrm{E}_{m}=\frac{\mathrm{RT}}{\mathrm{F}} \frac{u-v}{u+v} \ln \frac{a_{1}^{+} u+a_{1}^{-} v}{a_{2}^{+} u+a_{2}^{-} v}
\end{gathered}
$$

or at $20^{\circ} \mathrm{C}$ and in $\mathrm{mV}$ :

$$
\mathrm{E}_{m}=58 \frac{u-v}{u+v} \log \frac{a_{1}^{+} u+a_{1}^{-} v}{a_{2}^{+} u+a_{2}^{-} v}
$$

In the latter case the graph $\mathrm{E}_{m} v s . \log \frac{a_{1}^{+} u+a_{\mathbf{1}}^{-} v}{a_{2}^{+} u+a_{\mathbf{2}}^{-} v}$ should be a straight line with a slope $58 \frac{u-v}{u+v}$, giving zero potential for $a_{1}=a_{2}$ and being independent on the orientation of the membrane in the concentration gradient.

The experimental curves, though being straight lines in the concentration range studied, never conform to all these requirements. Most of them are shifted to lower potential differences (fig. I) and extrapolation shows that $\mathrm{E}_{m} \neq 0$ for $a_{1}=a_{2}$.
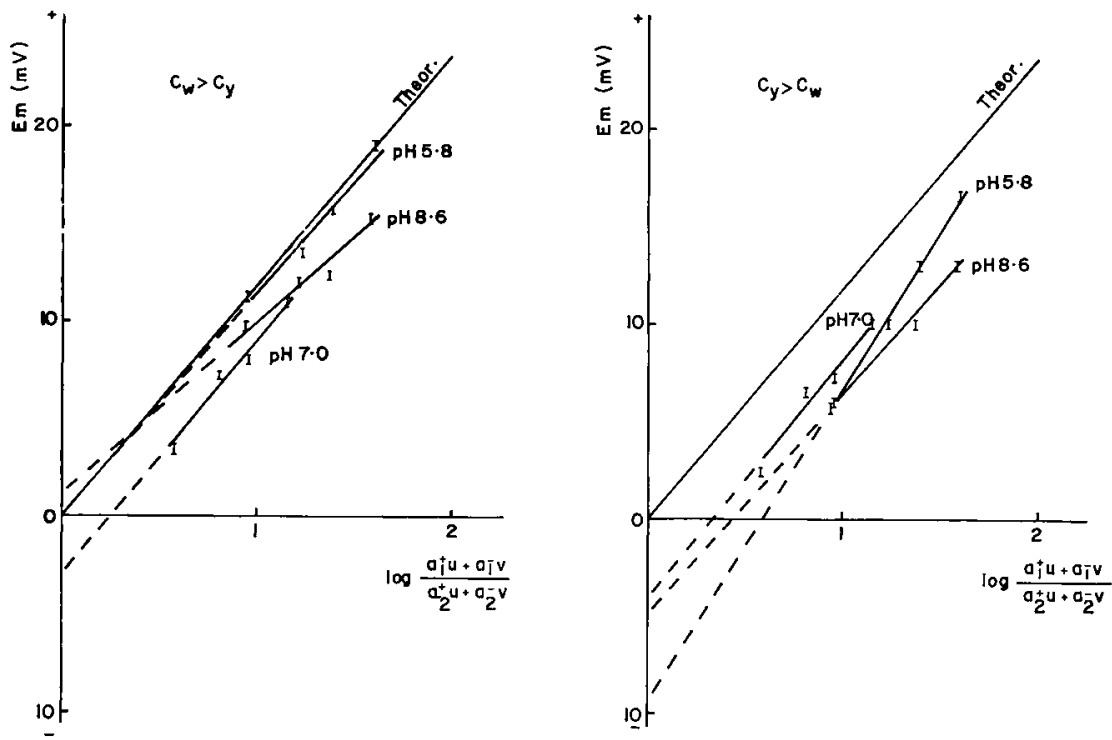

FIG. I. - Membrane potentials as a function of $\mathrm{NaCl}$ activity differences

Potentiels membranaires en fonction des différences d'activité de $\mathrm{NaCl}$

The + sign refers to the side with the highest concentration.

Le signe + indique le compartiment le plus concentré.

$\mathrm{E}_{\text {theor. }}$ was calculated with the values of $u$ and $v$ in solution.

$\mathrm{E}_{\mathrm{theor}}$. a été calculé en utilisant les valeurs de $u$ et $v$ en solution. 
Membrane asymmetry potentials : potential differences at equal NaCl concentrations on both sides. Correction is made for the junction potentials in the measuring circuit (see methods).

Potentiels résultant de l'asymétrie membranaire mesurés en présence d'une même solution de $\mathrm{NaCl}$ dans les deux compartiments. Les corrections pour les potentiels de jonction au long de la chaîne de mesure ont été effectuées (voir méthodes).

\begin{tabular}{|c|c|c|c|}
\hline \multicolumn{4}{|c|}{$\begin{array}{l}\text { Asymmetry potential in } \mathrm{mV}( \pm 0.25 \mathrm{mV}) \\
(+ \text { for white side })\end{array}$} \\
\hline $\mathrm{C} \mathrm{mol} / 1$ & pH 5.8 & $\mathrm{pH} 7.0$ & $\mathrm{pH} 8.6$ \\
\hline $10^{-3}$ & 1 & 2 & 2.5 \\
\hline $5 \cdot 10^{-3}$ & 0.5 & 1.75 & 2 \\
\hline $10^{-2}$ & 0.25 & 1.50 & 1.75 \\
\hline $5 \cdot 10^{-2}$ & 0 & 0.75 & 1.25 \\
\hline $10^{-1}$ & 0.25 & 0.75 & 1 \\
\hline $5 \cdot 10^{-1}$ & 0.25 & 0.75 & 0.75 \\
\hline
\end{tabular}

\section{TABLE 4}

Direction and values of $J_{\mathrm{s}}$ in phosphate diffusion experiments at various pH values for $\Delta C=0.0495 \mathrm{M}\left(\mathrm{C}_{1}=0.05 \mathrm{M} ; \mathrm{C}_{2}=0.0005 \mathrm{M}\right)$, compared to other electrolytes. For each salt, the experiments (in the two directions and at the different $\mathrm{pH}$ values) are performed with the same membrane, except for phosphate experiments, that require a statistical investigation (table 5 ).

Direction et valeurs de $J_{\mathrm{s}}$ phosphate à différentes valeurs de $p H$, pour $\Delta C=0,0495 \mathrm{M}$ $\left(\mathrm{C}_{1}=0,05 \mathrm{M} ; \mathrm{C}_{2}=0,005_{5} \mathrm{M}\right)$, comparées à d'autres électrolytes. Pour chaque électrolyte les essais (dans les deux directions, pour différentes valeurs de $\mathrm{pH}$ ) ont été exécutés en faisant emploi de la même membrane, exception faite pour le phosphate, qui nécessite une analyse statistique (table 5 ).

(I) The percentages are calculated against the greatest flux representing Ioo p. Ioo.

Les pourcentages sont calculés par rapport au plus grand flux qui représente roo p. Ioo.

\begin{tabular}{|c|c|c|}
\hline $\mathrm{pH}$ & Js: phosphate & $J_{s}:$ other salts tested $\left({ }^{1}\right)$ \\
\hline 5.8 & 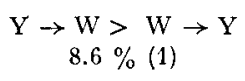 & \multirow{3}{*}{$\mathrm{Y} \rightarrow \mathrm{W} \simeq \mathrm{W} \rightarrow \mathrm{Y}$} \\
\hline 7.0 & $\mathrm{Y} \rightarrow \underset{68 \%}{\mathrm{~W}}>\mathrm{W} \rightarrow \mathrm{Y}$ & \\
\hline 8.6 & $Y \rightarrow \underset{42 \%}{W}>W \rightarrow Y$ & \\
\hline
\end{tabular}

(1) $\mathrm{NaCl} ; \mathrm{KCl} ; \mathrm{Na}_{2} \mathrm{SO}_{4} ; \mathrm{Na}_{2} \mathrm{HAsO}_{4}+\mathrm{NaH}_{2} \mathrm{AsO}_{4}$;

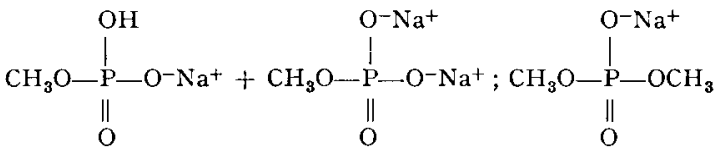



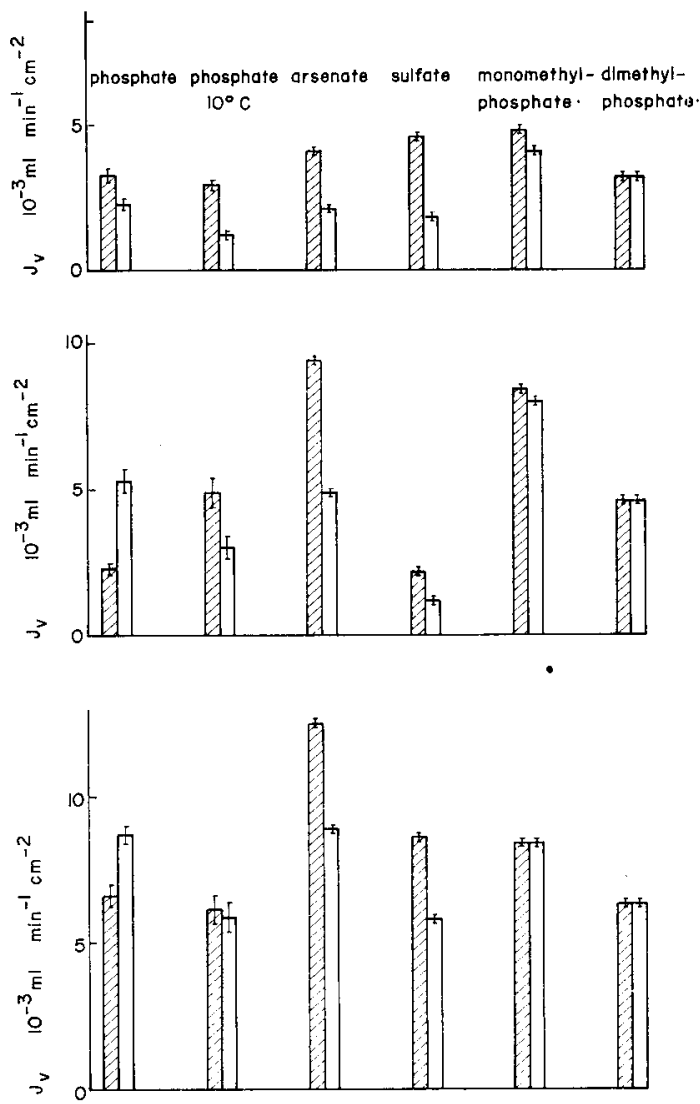

FIG. 2. - Qualitative and quantitative characteristics of $J_{v}$ for different electrolytes (*) at different $p H$ values. The shaded areas refer to the direction $\mathrm{W} \rightarrow \mathrm{Y}$. For each salt tested, except for phosphate, all experiments (in different directions and at different $\mathrm{pH}$ values) were performed with the same membrane.

Caractéristiques qualitatives et quantitatives de $J_{v}$ pour des électrolytes différents $\left(^{*}\right)$ en fonction du pH.

Les aires hachurées ont trait à la diffusion dans le sens blanc $\rightarrow$ jaune. Pour chaque électrolyte, à l'exception des ions phosphate, la série totale des essais a été faite au moyen de la même membrane. $\Delta \mathrm{C}=0.0495 \mathrm{M}\left(\mathrm{C}_{1}=0.05 \mathrm{M} ; \mathrm{C}_{2}=0.0005 \mathrm{M}\right)$.

* For $\mathrm{NaCl}$ and $\mathrm{KCl}$ no volume fluxes could be detected at any $\mathrm{pH}$ or concentration difference tested.

Pour des solutions de $\mathrm{NaCl}$ ou $\mathrm{KCl}$ le flux de volume était nul dans toutes conditions de $\mathrm{pH}$ et de concentration. 
Explanation is possible again on the basis of a charged membrane model where shifts are produced by the Donnan potentials. Moerover the shifts of the experimental curves, at the same $\mathrm{pH}$, are dependent on the orientation of the membrane in the concentration gradient, thus revealing an asymmetrical membrane. This conception was supported by potential measurements with equal $\mathrm{NaCl}$ concentrations in the bathing solutions (table 3). These "membrane asymmetry potentials " increase from $\mathrm{pH} 5.8$ to $\mathrm{pH} 8.6$ and decrease with increasing concentration. In this case their origin

\section{TABLE 5}

Statistical investigation of $J_{\mathrm{s}}$ phosphate

Analyse statistique de $J_{\mathrm{s}}$ phosphate

$\Delta \mathrm{C}=0.0495 \mathrm{M}\left(\mathrm{C}_{1}=0.05 \mathrm{M} ; \mathrm{C}_{2}=0.0005 \mathrm{M}\right)$.

$\mathrm{R}$ : regression coefficient for $\mathrm{J}_{s}$ vs. $\Delta \mathrm{C}$. coefficient de régression pour $\mathrm{J}_{s}$ vs. $\Delta \mathrm{C}$.

$\sigma_{\mathrm{R}}:$ standard deviation of $\mathrm{R}$. erreur standard pour $\mathrm{R}$.

$\mathrm{P}$ : probability according to the $t$-test of Student probabilité selon le " $t$-test " de Student

\begin{tabular}{|c|c|c|c|c|c|c|}
\hline \multirow{3}{*}{$\underset{10^{-4} \mathrm{~mol} \mathrm{l}^{-1}}{\Delta \mathrm{C}}$} & \multicolumn{6}{|c|}{$J_{s}$ in $10^{-4} \mathrm{mmol} \cdot \mathrm{min}^{-1} \cdot \mathrm{cm}^{-2}$} \\
\hline & \multicolumn{2}{|c|}{$\mathrm{pH} 5.8$} & \multicolumn{2}{|c|}{$\mathrm{pH} 7.0$} & \multicolumn{2}{|c|}{$\mathrm{pH} 8.6$} \\
\hline & $\mathrm{W} \rightarrow \mathrm{Y}$ & $\mathrm{Y} \rightarrow \mathrm{W}$ & $\mathrm{W} \rightarrow \mathrm{Y}$ & $Y \rightarrow W$ & $\mathrm{~W} \rightarrow \mathrm{Y}$ & $\mathrm{Y} \rightarrow \mathrm{W}$ \\
\hline \multirow[t]{2}{*}{245} & 2.1 & 2.2 & 1.6 & 2.6 & 1.9 & 2.4 \\
\hline & 3.1 & 2.1 & 1.2 & 2.6 & 1.7 & 2.8 \\
\hline \multirow[t]{2}{*}{495} & 5.7 & 6.5 & 3.6 & 10.4 & 3.2 & 5.0 \\
\hline & 5.3 & 5.5 & 3.6 & 11.8 & 2.8 & 5.4 \\
\hline \multirow[t]{2}{*}{745} & 8.1 & 7.3 & $\iota_{4.3}$ & 14.2 & 8.0 & 10.4 \\
\hline & 6.9 & 9.1 & 4.0 & 12.0 & 6.4 & 9.6 \\
\hline \multirow[t]{2}{*}{995} & 11.6 & 9.7 & 8.3 & 15.3 & 7.8 & 12.2 \\
\hline & 9.6 & 9.'́t & 8.3 & 18.9 & 8.6 & 13.8 \\
\hline $\begin{array}{c}\mathrm{R} \\
10^{-4} \mathrm{~cm} \cdot \mathrm{min}^{-1}\end{array}$ & $10^{\prime}$ & 98 & 85 & 182 & $9^{\prime}$ & 144 \\
\hline $10^{-4} \stackrel{\sigma \mathrm{R}}{\mathrm{cm}} \cdot \min ^{-1}$ & 8 & 12 & 11 & 27 & 12 & 10 \\
\hline$\stackrel{P}{R_{Y \rightarrow W}>R_{W} \rightarrow Y}$ & $30 \%<$ & $<40 \%$ & & $99 \%$ & $\mathrm{P}>$ & $99 \%$ \\
\hline
\end{tabular}

must be due to unequal Donnan distribution ratios at the two membrane boundaries. As, according to LAKshminarayanaIaH and SidDIQI (I97I), the Donnan distribution is governed by both fixed charge density and porosity, we conclude that one of these factors or both are different for the inner and the outer layer of the ovovitelline membrane, whose structures were already shown, by electron microscopy and amino acid analysis, to be different (BFLLAIRS et al., I963; BAIN and HALL, I969). 


\section{C. - Directional specificity of solute and volume fluxes for several electrolytes: the phosphate effect}

According to the results summarized in table 4 and fig. 2 the vitelline membrane exhibits particular properties with regard to phosphate ions between $\mathrm{pH} 7.0$ and 8.6.

The phosphate flux is absolutely dependent on the membrane orientation in the concentration gradient. This contrasts with the behaviour of other electrolytes, and even with that of arsenate and monomethylphosphate which are close to phosphate and carry the same charge in the $\mathrm{pH}$ range studied. The asymmetry is small at $\mathrm{pH} 5.8$ but evident at $\mathrm{pH} 7.0$ and 8.6 where phosphate ions diffuse about twice as fast from $\mathrm{Y} \rightarrow \mathrm{W}$ than from $\mathrm{W} \rightarrow \mathrm{Y}$ (table 5). This may be relevant to the statement of Hevesy et al. (1938) that ${ }^{32} \mathrm{P}$ remains in white for a long period.

\section{TABLE 6}

Statistical investigation of $J_{\mathrm{v}}$ in phosphate diffusion experiments

Analyse statistique du fux de volume dans les essais avec le ion phosphate

$$
\begin{aligned}
& \Delta \mathrm{C}=0.0495 \mathrm{M}\left(\mathrm{C}_{1}=0.05 \mathrm{M} ; \mathrm{C}_{2}=0.0005 \mathrm{M}\right) \text {. } \\
& \overline{\mathrm{J}}_{v}: \mathrm{J}_{v} \text { averaged. } \\
& \text { la moyenne de } \mathrm{J} v \text {. } \\
& \sigma_{\overline{\mathrm{J}}} \text { : standard deviation of } \overline{\mathrm{J}}_{v} \text {. } \\
& \text { erreur standard de la moyenne } \overline{\mathrm{J}}_{v} \text {. } \\
& \mathrm{P} \text { : see table } 5 \\
& \text { voir tableau } 5
\end{aligned}
$$

\begin{tabular}{|c|c|c|c|c|c|c|}
\hline & \multicolumn{6}{|c|}{$\mathrm{J}_{v}$ in $10^{-3} \mathrm{ml} \cdot \mathrm{min}^{-1} \cdot \mathrm{cm}^{-2}$} \\
\hline & \multicolumn{2}{|c|}{ pH 5.8} & \multicolumn{2}{|c|}{$\mathrm{pH} 7.0$} & \multicolumn{2}{|c|}{$\mathrm{pH} 8.6$} \\
\hline & $\mathrm{Y} \rightarrow \mathrm{W}$ & $\mathrm{W} \rightarrow \mathrm{Y}$ & $\mathrm{Y} \rightarrow \mathrm{W}$ & $\mathrm{W} \rightarrow \mathrm{Y}$ & $\mathrm{Y} \rightarrow \mathrm{W}$ & $\mathrm{W} \rightarrow \mathrm{Y}$ \\
\hline & 1.70 & 2.75 & 4.10 & 1.85 & 7.90 & 6.60 \\
\hline & 2.75 & 3.80 & 5.30 & 2.45 & 8.75 & 5.30 \\
\hline & 2.40 & 3.50 & 5.30 & 2.15 & 8.20 & 7.00 \\
\hline & 1.80 & 3.90 & 6.50 & 2.70 & 9.55 & 7.95 \\
\hline & 2.10 & 2.95 & 4.00 & 3.10 & 9.10 & 6.25 \\
\hline & 2.85 & 2.45 & 6.50 & 1.50 & & \\
\hline$\overline{\mathrm{J}}_{v}$ & 2.25 & 3.25 & 5.30 & 2.30 & 8.70 & 6.60 \\
\hline \multirow[t]{2}{*}{$\sigma_{\bar{J} v}^{-}$} & 0.20 & 0.25 & 0.40 & 0.20 & 0.30 & 0.40 \\
\hline & \multicolumn{2}{|c|}{$\begin{aligned} \mathrm{P}_{J_{v}}(\mathrm{~W} \rightarrow \mathrm{Y})>\mathrm{J}_{v}(\mathrm{Y} \rightarrow \mathrm{W}) \\
\\
\simeq 99 \%\end{aligned}$} & \multicolumn{2}{|c|}{$\begin{aligned} \mathrm{P}_{J_{v}}(\mathrm{Y} \rightarrow & \mathrm{W})>\mathrm{J}_{v}(\mathrm{~W} \rightarrow \mathrm{Y}) \\
& >99,9 \%\end{aligned}$} & \multicolumn{2}{|c|}{$\begin{aligned} \mathrm{P}_{J_{v}}(\mathrm{Y} \rightarrow & \mathrm{W})>\mathrm{J}_{v}(\mathrm{~W} \rightarrow \mathrm{Y}) \\
& >99 \%\end{aligned}$} \\
\hline
\end{tabular}

The $\mathrm{J}_{v}$-asymmetry, if present, has always the same direction for all electrolytes including arsenate and monomethyl-phosphate i.e. $\mathrm{J}_{v}(\mathrm{~W} \rightarrow \mathrm{Y})>\mathrm{J}_{v}(\mathrm{Y} \rightarrow \mathrm{W})$ The same holds for phosphate at $\mathrm{pH} 5.8$, but between $\mathrm{pH} 7.0-8.6 \mathrm{~J} v(\mathrm{Y} \rightarrow \mathrm{W})$ $>\mathrm{J}_{v}(\mathrm{~W} \rightarrow \mathrm{Y})($ table 6$)$. These results may be relevant to the well known water 
transport occurring from $\mathrm{W} \rightarrow \mathrm{Y}$ in the laid egg, that can be restrained if the outside layer of the vitelline membrane is protected by stabilization of the $\mathrm{pH}$ of the white (Fromm and Gammon, I968). Moreover only in phosphate solutions successive experiments with the same membrane are not reproducible; an irreversible change seems to occur. We may assume that phosphate ions interact somehow specifically with the ovovitelline membrane between $\mathrm{pH}$ 7.0-8.6, thereby changing its permeability properties. The following findings corroborate this assumption :

I. Conditioning the membrane a few hours in $0.05 \mathrm{M}$ phosphate $\mathrm{pH} 7.0$ (at this $\mathrm{pH}$ the differences in phosphate flux with regard to the direction are most evident) gives no longer a difference in $\mathrm{J}_{\delta}$ in a subsequent phosphate diffusion experiment. The $\mathrm{J} v$-asymmetry however persists.

2. Phosphate diffusion experiments in $0.5 \mathrm{M} \mathrm{NaCl}$ at any $\mathrm{pH}$ no longer result into an asymmetrical $\mathrm{J}_{s}$ (table 7 ). The volume fluxes are hardly measurable. High $\mathrm{NaCl}$ concentrations thus interfere with the phosphate-membrane interaction.

\section{TABLE 7}

Statistical investigation of $J_{\mathrm{s}}$ phosphate in $0.5 \mathrm{M} \mathrm{NaCl}$

Analyse statistique de $J_{\mathrm{s}}$ phosphate en présence de $0,5 \mathrm{M} \mathrm{NaCl}$

$$
\begin{gathered}
\Delta \mathrm{C}=0.0495 \mathrm{M}\left(\mathrm{C}_{1}=0.05 \mathrm{M} ; \mathrm{C}_{2}=0.0005 \mathrm{M}\right) \\
\overline{\mathrm{J}}_{s}, \sigma_{\overline{\mathrm{J}}_{s}}, \mathrm{P}: \text { see tables } 5 \text { and } 6 \\
\quad \text { voir tableaux } 5 \text { et } 6
\end{gathered}
$$

\begin{tabular}{|c|c|c|c|c|c|c|}
\hline & \multicolumn{6}{|c|}{$\mathrm{J}_{s}$ phosphate in $10^{-4} \mathrm{mmol} \cdot \mathrm{min}^{-1} \cdot \mathrm{cm}^{-2}$} \\
\hline & \multicolumn{2}{|c|}{$\mathrm{pH} 5.8$} & \multicolumn{2}{|c|}{$\mathrm{pH} 7.0$} & \multicolumn{2}{|c|}{$\mathrm{pH} 8.6$} \\
\hline & $\mathrm{Y} \rightarrow \mathrm{W}$ & $\mathrm{W} \rightarrow \mathrm{Y}$ & $\mathrm{Y} \rightarrow \mathrm{W}$ & $\mathrm{W} \rightarrow \mathrm{Y}$ & $\mathrm{Y} \rightarrow \mathrm{W}$ & $\mathrm{W} \rightarrow \mathrm{Y}$ \\
\hline & 5.5 & 4.7 & 0.2 & 6.2 & 6.6 & 5.0 \\
\hline & 5.9 & 6.6 & 5.4 & 6.4 & 5.0 & 6.9 \\
\hline & 8.7 & 6.1 & 6.7 & 8.0 & 6.5 & 7.1 \\
\hline & 7.6 & 6.1 & 6.0 & 5.9 & 7.2 & 4.9 \\
\hline & 6.6 & 7.5 & 8.0 & 8.0 & 5.7 & 8.1 \\
\hline & 6.0 & 7.5 & 6.3 & 5.7 & 6.4 & 5.5 \\
\hline$\overline{\mathrm{J}}_{s}\left({ }^{(1)}\right.$ & 6.7 & 6.4 & 6.4 & 6.7 & 6.2 & 6.3 \\
\hline$\sigma \vec{J}_{s}\left({ }^{2}\right)$ & 0.5 & 0.5 & 0.4 & 0.4 & 0.4 & 0.5 \\
\hline $\mathrm{P}_{J_{s}}(\mathrm{Y} \rightarrow \mathrm{W})=\mathrm{J}_{s}(\mathrm{~W} \rightarrow \mathrm{Y})\left(^{3}\right)$ & \multicolumn{2}{|c|}{$60-70 \%$} & \multicolumn{2}{|c|}{$60-70 \%$} & \multicolumn{2}{|c|}{$80-90 \%$} \\
\hline
\end{tabular}

3. Phosphate diffusion experiments at $\mathrm{IO}^{\circ} \mathrm{C}$, with $\Delta \mathrm{C}=0.0495 \mathrm{M}, \mathrm{pH}$ 7.0, no longer show the asymmetrical $\mathrm{J}_{s}$ found at $20^{\circ} \mathrm{C}$ and $\mathrm{J}_{v}(\mathrm{~W} \rightarrow \mathrm{Y})>\mathrm{J}_{v}(\mathrm{Y} \rightarrow \mathrm{W})$ by $3^{8} \mathrm{p}$. roo, thus giving the same relative results as sulphate and arsenate diffusion (fig. 2 and table 8). The temperature dependance of the membrane-phosphate interaction is thus established. 
TABLE 8

$J_{\mathrm{s}}$ and $J_{\mathrm{v}}$ in phosphate diffusion experiments at $10^{\circ} \mathrm{C}$

$J_{\mathrm{s}}$ et $J_{\mathrm{v}}$ pour le ion phosphate à $10^{\circ} \mathrm{C}$

$\Delta \mathrm{C}=0.0495 \mathrm{M}\left(\mathrm{C}_{1}=0.05 \mathrm{M} ; \mathrm{C}_{2}=0.0005 \mathrm{M}\right)$

Symbols : see tables 5 and 6

Symboles : voir tableaux 5 et 6

TABLE $8 a$

\begin{tabular}{|c|c|c|c|c|c|c|}
\hline & \multicolumn{6}{|c|}{$\mathrm{J}_{s}$ in $10^{-4} \mathrm{mmol} \cdot \mathrm{min}^{-1} \cdot \mathrm{cm}^{-2}$} \\
\hline & \multicolumn{2}{|c|}{ pH 5.8} & \multicolumn{2}{|c|}{$\mathrm{pH} 7.0$} & \multicolumn{2}{|c|}{$\mathrm{pH} 8.6$} \\
\hline & $\mathrm{Y} \rightarrow \mathrm{W}$ & $\mathrm{W} \rightarrow \mathrm{Y}$ & $\mathrm{Y} \rightarrow \mathrm{W}$ & $W \rightarrow Y$ & $\mathrm{Y} \rightarrow \mathrm{W}$ & $W \rightarrow Y$ \\
\hline & 4.70 & 4.60 & 2.80 & 2.60 & 6.20 & 4.90 \\
\hline & 4.60 & 5.90 & 3.20 & 3.80 & 4.10 & 3.20 \\
\hline & 5.80 & 7.40 & 4.70 & 5.30 & 5.50 & 5.80 \\
\hline & 3.30 & 4.90 & 5.80 & 4.90 & 3.00 & 5.40 \\
\hline & 6.10 & 6.20 & 5.60 & 4.10 & 3.00 & 4.30 \\
\hline & 6.60 & 3.60 & 3.30 & 4.90 & 4.40 & 3.00 \\
\hline$\overline{\mathrm{J}}_{s}$ & 5.18 & 5.43 & 4.23 & 4.27 & 4.37 & 4.43 \\
\hline$\sigma \overline{\mathbf{J}}_{\boldsymbol{s}}$ & 0.50 & 0.55 & 0.54 & 0.40 & 0.53 & 0.47 \\
\hline
\end{tabular}

TABLE $8 b$

\begin{tabular}{|c|c|c|c|c|c|c|}
\hline & \multicolumn{6}{|c|}{$\mathrm{J}_{v}$ in $10^{-3} \mathrm{ml} \cdot \mathrm{min}^{-1} \cdot \mathrm{cm}^{-2}$} \\
\hline & \multicolumn{2}{|c|}{ pH 5.8} & \multicolumn{2}{|c|}{$\mathrm{pH} 7.0$} & \multicolumn{2}{|c|}{$\mathrm{pH} 8.6$} \\
\hline & $\mathrm{Y} \rightarrow \mathrm{W}$ & $\mathrm{W} \rightarrow \mathrm{Y}$ & $\mathrm{Y} \rightarrow \mathrm{W}$ & $\mathrm{W} \rightarrow \mathrm{Y}$ & $\mathrm{Y} \rightarrow \mathrm{W}$ & $W \rightarrow Y$ \\
\hline & 1.70 & 3.31 & 2.55 & 5.09 & 6.07 & 5.30 \\
\hline & 1.36 & 3.35 & 4.50 & 6.79 & 7.64 & 6.92 \\
\hline & 0.85 & 2.12 & 3.48 & 4.16 & 6.28 & 8.15 \\
\hline & 0.91 & 2.76 & 2.76 & 3.23 & 4.37 & 5.52 \\
\hline & 0.85 & 3.06 & 1.91 & 4.58 & 6.24 & 6.03 \\
\hline & 1.41 & 2.90 & 3.01 & 5.52 & 4.50 & 4.75 \\
\hline $\bar{J}_{v}$ & 1.19 & 2.92 & 3.04 & 4.90 & 5.85 & 6.11 \\
\hline$\sigma \bar{\jmath}_{v}$ & 0.14 & 0.18 & 0.37 & 0.49 & 0.5 & 0.5 \\
\hline
\end{tabular}


T. RYMEN, J. STOCKX

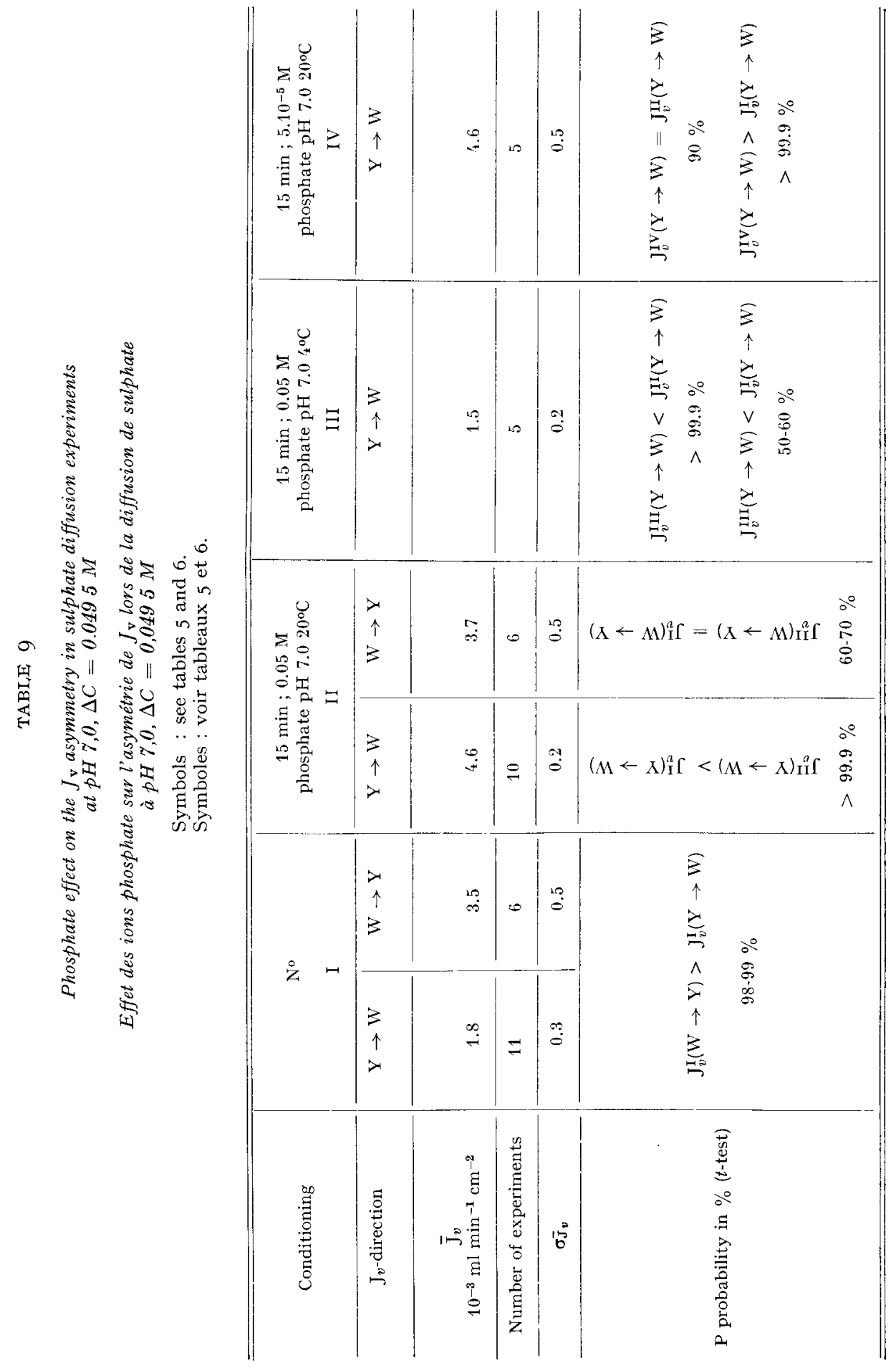


4. When using membranes, previously conditioned in $0.05 \mathrm{M}$ phosphate $\mathrm{pH} 7.0$ and carefully washed in redistilled water, in sulphate diffusion experiments.

$$
\left(\Delta \mathrm{C}_{\mathrm{Na}_{2} \mathrm{sO}_{4}}=0.0495 \mathrm{M} ; \mathrm{pH} 7.0\right),
$$

$\mathrm{J}_{s}$ has the same value in both directions but $\mathrm{J}_{v}(\mathrm{Y} \rightarrow \mathrm{W})$ shows a two to three fold increase while $J_{v}(\mathrm{~W} \rightarrow \mathrm{Y})$ remains unchanged so that qualitatively the same $\mathrm{J}_{v^{-}}$asymmetry obtains as for phosphate solutions (table 9 ).

The influence of previous conditioning in $0.05 \mathrm{M}$ phosphate $\mathrm{pH} 7.0$ on $\mathrm{J} v(\mathrm{Y} \rightarrow \mathrm{W})$ in sulphate diffusion experiments at $\mathrm{pH} 7.0$ and $\Delta \mathrm{C}=0.0495 \mathrm{M}$, was followed as a function of time : the effect shows up rather rapidly (the shortest observation time was five minutes) and then remains rather constant for pretreatment times within two hours. Conditioning during longer periods decreases the effect gradually; after ten hours no influence could be seen at all (fig. 3) ;

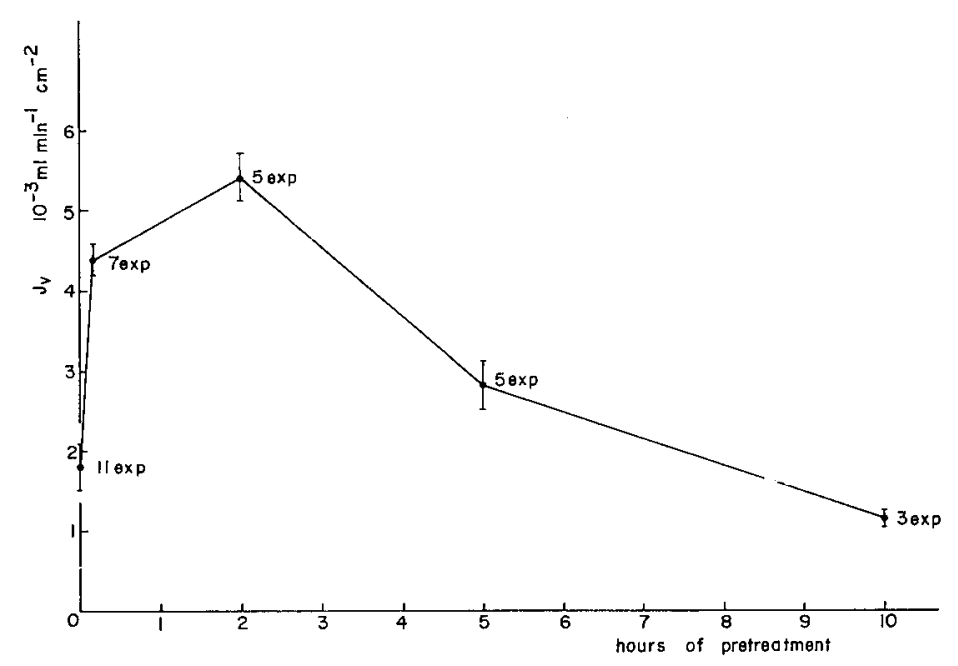

FIG. 3. - The phosphate effect on $J_{v}(\mathrm{Y} \rightarrow \mathrm{W})$

in sulphate diffusion experiments at $p H 7.0$ as a function of pretreatment time

Effet des ions phosphate sur $J_{v}(\mathrm{Y} \rightarrow \mathrm{W})$ dans des essais de diffusion de sulphate $\grave{a} p H 7,0$, en fonction de la durée du traitement préalable

$$
\Delta \mathrm{C}=0.0495 \mathrm{M}\left(\mathrm{C}_{1}: 0.05 \mathrm{M} ; \mathrm{C}_{2}: 0.0005 \mathrm{M}\right)
$$

- concentration : the results are rather constant for all concentrations between $5 \times 10^{-5} \mathrm{M}$ and $5 \times 10^{-2} \mathrm{M}$ (table 9);

- temperature : after conditioning at $4^{\circ} \mathrm{C}$ in $0.05 \mathrm{M}$ phosphate $\mathrm{pH} 7.0$ and washing at $4^{\circ} \mathrm{C}$, no increase in $\mathrm{J}_{v}(\mathrm{Y} \rightarrow \mathrm{W})$ is observed in subsequent sulphate diffusion experiments $\left(\Delta \mathrm{C}=0.0495 \mathrm{M} ; \mathrm{pH} 7.0 ; 20^{\circ} \mathrm{C}\right)$ (table 9);

- ionic strength : when conditioning during $\mathrm{I}_{5}$ minutes in $0.0 \mathrm{O} \mathrm{M}$ phosphate $\mathrm{pH} 7.0$ in increasing $\mathrm{NaCl}$ concentrations, the effect disappears for $\mathrm{C}_{\mathrm{NaCl}}=0.25 \mathrm{M}$. In $0.05 \mathrm{M}$ phosphate in stops at o.I $\mathrm{M} \mathrm{NaCl}$. These results make it highly improbable that the influence of increasing $\mathrm{NaCl}$ concentrations should be explained by assuming an ion exchange competition effect (table ro). 
5. Phosphate determinations showed that membrane homogenates containing approximetely 6 membranes, treated during 4 hours with $0.05 \mathrm{M}$ phosphate $\mathrm{pH} 7.0$ at $25^{\circ} \mathrm{C}$ and washed with redistilled water until a conductivity of Io $\mu \mathrm{S}$, contained approximately $9 \mu \mathrm{g} \mathrm{P}$ more than untreated homogenates that contain only $2 \mu \mathrm{g}$ P. Assuming an average dry weight of $5 \mathrm{mg}$ for the ovovitelline membrane, only $0.3 \mu \mathrm{g} \mathrm{P}$ would be taken up per mg membrane. This would correspond to an average of one $P$ atom per protein of MW IOo ooo, assuming that the membrane consists of IOo p. IOo protein. This is only a very rough estimate as amino acid analysis by BELLAIRS $e t$ al. (I963) points to a total of $66-78$ p. Ioo amino acid residues in different layers of the hen's ovovitelline membrane.

\section{TABLE IO}

Phosphate effect on $J_{\mathrm{v}}(\mathrm{Y} \rightarrow \mathrm{W})$ in sulphate diffusion experiments at $p H \% .0$

$(\Delta \mathrm{C}=0.0495 \mathrm{M})$ as a function of $\mathrm{NaCl}$ concentration in the conditioning medium

Effet des ions phosphate en fonction de la concentration de $\mathrm{NaCl}$ dans le milieu Symbols : see table 6.

Symboles : voir tableau 6.

\begin{tabular}{|c|c|c|c|c|c|c|}
\hline \multirow[b]{3}{*}{$\mathrm{C}_{\mathrm{NaCl}} \mathrm{mol} \cdot \mathrm{1}^{-1}$} & \multicolumn{6}{|c|}{$\mathrm{J}_{v}$ in $10^{-3} \mathrm{ml} \cdot \min ^{-1} \cdot \mathrm{cm}^{-2}$} \\
\hline & \multicolumn{4}{|c|}{$10^{-2} \mathrm{M}$ phosphate } & \multicolumn{2}{|c|}{$5 \cdot 10^{-2} \mathrm{M}$ phosphate } \\
\hline & $10^{-2}$ & $5 \cdot 10^{-2}$ & $10^{-1}$ & $2.5 \cdot 10^{-1}$ & $5 \cdot 10^{-2}$ & $10^{-1}$ \\
\hline & $\begin{array}{l}5.70 \\
5.10 \\
5.35 \\
5.25 \\
5.25 \\
3.85\end{array}$ & $\begin{array}{l}4.75 \\
3.65 \\
5.15 \\
5.80 \\
6.30\end{array}$ & $\begin{array}{l}4.65 \\
3.45 \\
5.70 \\
4.60 \\
4.65 \\
3.80\end{array}$ & $\begin{array}{l}2.80 \\
0.15 \\
0.35 \\
0.50 \\
1.35 \\
0.90 \\
0.50 \\
0.85\end{array}$ & $\begin{array}{l}3.80 \\
5.30 \\
6.20 \\
4.90 \\
5.45 \\
4.05\end{array}$ & $\begin{array}{l}0.55 \\
1.25 \\
0.55 \\
0.25 \\
0.70 \\
0.40\end{array}$ \\
\hline $\overrightarrow{\mathrm{J}} v$ & 5.10 & 5.15 & 4.50 & 0.95 & 4.96 & 0.60 \\
\hline$\sigma_{\bar{J} \boldsymbol{v}}$ & 0.2 & 0.4 & 0.3 & 0.3 & 0.4 & 0.15 \\
\hline
\end{tabular}

\section{CONCLUSION}

The vitelline membrane of the unfertilized hen's egg is an asymmetrical ion exchange membrane. This asymmetry has no mentionable influence on $\mathrm{J}_{s}$ for most electrolytes but induces asymmetrical membrane potentials and volume fluxes.

Only the phosphate flux is direction dependent, probably as the result of a specific direction dependent phosphate-membrane interaction retarding the diffusion of this ion. This interaction also reverses the $\mathrm{J} v$-asymmetry, with regard to that 
found for the other electrolytes, by enchancing $\mathrm{J}_{v}(\mathrm{Y} \rightarrow \mathrm{W})$. Schulz reported already in 1959 that the adsorption of diphosphate anions on the synthetic anion exchange membrane "Permaplex A-Io " reverses the direction of the electroosmotic water transfer by reversing the resin charge. Though the effect of the interaction vitelline membrane-phosphate anions possibly should be explained in the same way, its cause seems to be quite different from a simple ion exchange effect (non-reproducibility, concentration, temperature, ionic strength and time dependence).

The time dependence suggests that the interaction proceeds in several steps while non-reproducibility points to the fact that at least in vitro one of them should be irreversible. Bearing in mind the important influence of temperature, the participation of one or more enzymes does not seem impossible.

Investigations are in progress in order to get more information about the nature of this interaction that is supposed to be at the basis of a biologically mediated osmoregulating mechanism. An interacting possibility is the type of membrane protein phosphorylation reported by DEAMER and BASKIN (I972) and by MAKINOSE (I972) in sarcoplasmic reticulum membranes, consisting in a reversal of the membrane A'TP-ase mediated ATP splitting reactions.

Recu pour publication en janvier 1974.

\title{
RÉSUMÉ
}

\begin{abstract}
LA MEMBRANE VITELIINE DE L'GEUF DE POULE NON FÉCONDÉ :
\end{abstract} TRANSPORT DE L'EAU ET DES ÉLECTROLYTES

L'étude de la diffusion de plusieurs électrolytes à travers la membrane vitelline de l'œuf de poule non fécondé et de ses potentiels électriques mène à la conclusion qu'on sc trouve en face d'une membrane chargée se comportant de façon asymétrique. Son asymétrie directionelle visà-vis du transport ionique et du flux de volume qui s'ensuit sont décrits pour plusieurs électrolytes. Le ion phosphate exerce un effet très spécifique. L'interaction membrane-phosphate dépend de divers facteurs (force ionique, température et durée). Elle semble bien plus complexe que si elle était due uniquement à un simple échange d'ions. Un mécanisme enzymatique n'est pas exclu.

\section{REFERENCES}

Bain J. M., Hall J. M., rg69. Observations on the development and structure of the vitelline membrane of the hen's egg: an electron microscopy study. Aust. J. Biol. Sci., 22, 653-665.

Bellairs R., Harkness M., Harkness R. D., 1963. The vitelline membrane of the hen's egg: a chemical and electron microscopical study. J. Ultrastruct. Res., 8, 339-359.

Burmaster C., I946. Microdetermination of $\alpha$ - and $\beta$-glycerophosphates. J. Biol. Chem., 164, $233-240$.

Deamer D. W., Baskin R. J., 1972, ATP synthesis in Sarcoplasmic Reticulum. Arch. Biochem. Biophys., 153, 47-54.

De Bofck S., De Moor M., Stockx J., I97r. Permeation properties of the ovovitelline membrane of the hen's egg. Arch. internat. Physiol. Biochim., 79, 359-368.

De Moor M., Stockx J., 1969. Aggregation-dissociation equilibria of the hen's egg-white ribonuclease. Arch. internat. Physiol. Biochim., 17\%, 547-548.

Etheredge E., HaAland J. E., Rosenberg M. D., I971. The functional properties of ATP-ases bound to and solubilized from the membrane complex of the hen's egg. Biochim. Biophys. Acta, 233, 145-154. 
Fromm D., Gammon S. U., 1968. Specific gravity and volume of the hen's egg as influenced by albumin $\mathrm{pH}$ and storage age of the egg. Poultry Sci., 47, II9I-IIg6.

Gilbert A. B., I97ז. The egg : its physical and chemical aspects. Physiology and Biochemistry of the Domestic Fowl, 3, I379-1399. Éd. D. J. Bell and B. M. Freeman, Academic Press, London, New York.

Glasstone S., I946. Textbook of Physical Chemistry. p. 959 and 967 (and éd., Van Nostrand, D. et Co, Inc.).

Haaland J. E., Etheredge E., Rosenberg M. D., I97I. Isolation of an ATP-ase from the membrane complex of the hen's egg. Biochim. Biophys. Acta, 233, I37-144.

Hevesy G. C., Levi H. B., RebBe O. G., 1938. The origin of the phosphorus compounds in the embryo of the chicken. Biochem. J. 32, 2 I 47-2, 55 .

Jordanov J., Georgiev I., Boyadjieva-mihailova A., i966. Physicochemical and electronmicroscopical investigations on the vitelline membrane of the hen's egg with a view to its permeability to macromolecules. Compt. Rend. Acad. Bulg. Sci., 19, I53-I 56.

Kenzo K., I929. Zur Kenntnis des Cholesterinstoffwechsels im bebrüteten Ei. Zeitschr. f. physiol. Chem., 181, IOI-Io6.

Lakshminarayanaiah N., I969. Transport Phenomena in Membranes p. 5. Academic Press, New York and London.

Lakshminarayanaiah N., Siddigi F. A., r971. Studies with composite membranes: preparation and measurements of impedances. Biophys. J., 11, 603-616.

Makinose M., 1972. Phosphoprotein formation during osmochemical energy conversion in the membrane of the Sarcoplasmic Reticulum. F. E. B. S. Letters, 25, II3-II5.

Moors A., Sтоскx J., I968. Alkaline and acid phosphomono-esterase and phosphodiesterase activities in chicken eggs. II. Arch. internat. Physiol. Biochim., 76, I95-I97.

Moors A., I969. Onderzoek van fosfomonoësterase- en fosfodiësterase aktiviteiten van kippeëieren. Thesis Rijksuniversiteit Gent.

Needham J., I93I. The relations between white and yolk in the hen's egg. V. The osmotic properties of the isolated vitelline membrane. J. Exptl. Biol., 8, 330-344.

Needham J.,I950. Biochemistry and Morphogenesis. Cambridge at the University Press.

Orru A., r939. Permeabilita della membrana vitellina del tuorlo dell' uovo di gallina all'acqua e fattori che la modificano: nota I. Arch. Sci. Biol., 25, 292-308.

ORRU A., I940. Permeabilita della membrana vitellina del tuorlo dell' uovo di gallina all'acqua e fattori che la modificano : nota II. Arch. Sci. Biol., 26, 32-50.

Pucher G. W., 1927. Chemical analysis of incubated non-fertile eggs. Proc. Soc. Exptl. Biol. Med., 25, 72-73.

Rhea R. P., Rosenberg M. D., I97I. ATP-ase activities of inner and outer regions of the vitelline membrane during development. Develop. Biol. 26, 6r6-626.

Rice F. E., Young D. L., rg28. Osmotic activity in eggs of different age of the common fowl. Poult. Sci., 7, $116-118$.

Romanof A. L., Romanoff A. J., I949. The Avian Egg. John Wiley and sons, Inc., New York.

Romanof A. L., I96o. The Avian Embryo. The MacMillan Company, New York.

Schulz G., I959. Uberführungsversuche mit Natriumchlorid und Natriumdiphosphat an einer Anionenaustauschmembran. Z. anorg. allg. Chemie, 301, 97-108,

Smith M., Shepherd J., I93i. The relations between withe and yolk in the hen's egg. II. Osmotic equilibration. J. Exptl. Biol., 8, 293-3II.

Straub J., Hoogerdurn M. J. T., 1929. Der Unterschied in osmotischer Konzentration zwischen Eigelb und Eiklar. Rec. trav. chim. Pays-Bas, 48, 49-82.

Teorell T., 1953. Transport Processes in ionic membranes. Progr. Biophys. Biophysical Chem., 3, 305-369.

Van Maele A., 1969. Studie van nucleoside trifosfaat fosfohydrolase werking in wit van kippeëi. Thesis Rijksuniversiteit Gent.

WLadimirofF G. E., r926. Einige physikalisch-chemische Veränderungen des Eiereiweiszes sich entwickelnder Hühnereier. Biochem. Zeitschr., 179, 280-297. 